\title{
Characteristic imaging findings in pulmonary fat embolism syndrome (FES)
}

\author{
Sidney Ching Liang Ong, ${ }^{1}$ Viknesh Balasingam ${ }^{2}$
}

${ }^{1}$ Radiology Department, Clinical Campus, International Medical University, Seremban, Negeri Sembilan, Malaysia ${ }^{2}$ Department of Diagnostic Imaging, Hospital Tuanku Ja'afar, Seremban, Negeri Sembilan, Malaysia

Correspondence to Dr Sidney Ching Liang Ong, sidney_ong@yahoo.co.uk

Accepted 11 November 2017

\section{CrossMark}

To cite: Ong SCL, Balasingam V. BMJ Case Rep Published Online First: [please include Day Month Year]. doi:10.1136/bcr-2017223007

\section{DESCRIPTION}

A 21-year-old male presented to the hospital following a road accident. He was riding a motorcycle when he flung into a roadside drain. On arrival, his Glasgow Coma Scale was 15/15 and vital signs were stable. On examination, there was tenderness and deformity of the left thigh. The diagnosis of closed comminuted fractures of the left femur was confirmed following plain radiography. Chest radiograph was normal (figure 1). He was admitted and planned for interlocking nail (ILN) insertion at the left femur. Two days after admission, his blood oxygen saturation $\left(\mathrm{SpO}_{2}\right)$ became low at $92 \%$ despite $3 \mathrm{~L}$ of oxygen. He was febrile and tachycardic. On day 3 , he developed chest pain, palpitations and tachypnoea. Oxygen support was escalated to intubation and mechanical ventilation. Chest radiograph then showed diffuse air space opacities bilaterally (figure 1). CT pulmonary angiogram showed diffuse ground-glass opacities and consolidations in both lung fields with relative sparing of anterior segments of both upper lobes (figure 2). Multiple ill-defined nodules $(<5 \mathrm{~mm})$ were seen at the right upper lobe (figure 2). There were also small filling defects within the left lower lobe pulmonary artery. He was diagnosed to have fat embolism syndrome (FES) and was given supportive treatment at the intensive care unit for 5 days. His lung conditions improved and he was discharged from the hospital uneventfully following ILN insertion.

Fat embolism is defined by the presence of fat globules in the pulmonary circulation. FES refers to clinical syndrome that follows an identifiable insult which releases fat into the circulation, resulting in pulmonary and systemic symptoms. ${ }^{1}$

While fat embolism occurs in $>90 \%$ of patients with traumatic skeletal injuries, FES occurs in only $3-4 \% .^{2}$ Pulmonary manifestations are the most common but variable combination

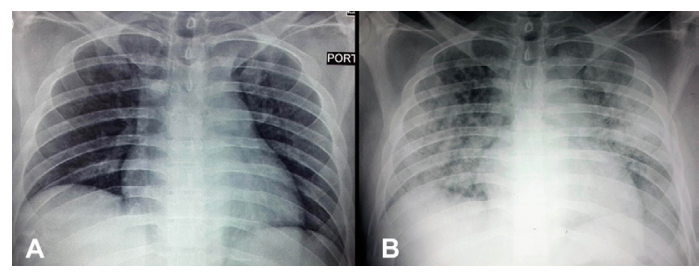

Figure 1 (A) Chest radiograph on admission was normal. (B) Chest radiograph on day 3 of admission showed bilateral diffuse air space opacities.

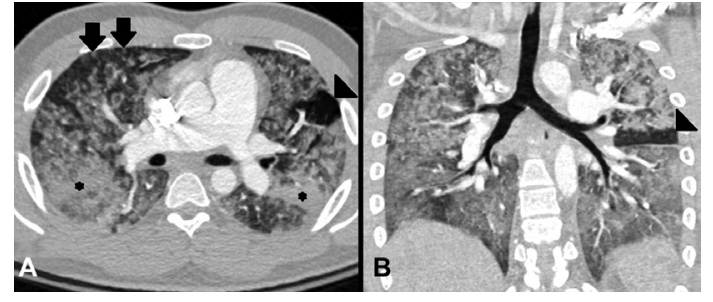

Figure 2 Selected CT pulmonary angiogram in lung window setting at axial (A) and coronal (B) sections showing diffuse ground-glass opacities with smooth septal thickenings bilaterally. Also shown are ill-defined nodules (arrows), segmental sparing of left upper lobe (arrowheads) and consolidations at dependent portions (asterisks).

of pulmonary, cerebral and cutaneous symptoms can happen. Symptoms typically appear 12-72 hours after a traumatic event, before which there are no preceding clinical or radiographic abnormalities. ${ }^{1-3}$ The pathophysiology of FES is unknown, but there are two widely accepted theories. The first is mechanical obstruction of pulmonary circulation by fat lobules released from trauma to the adipose tissue or fatty marrow. The biochemical theory involves degradation of embolised fat into toxic intermediaries with pro-inflammatory effects. ${ }^{1}$ The latter could explain the typical delay of FES symptoms up to 72 hours.

Radiographic appearance remains normal in milder cases. ${ }^{2}$ Generally however, chest radiography findings are not dissimilar to acute respiratory distress syndrome from other causes and

\section{Learning points}

Fat embolism syndrome (FES) should be suspected if there are acute pulmonary, cerebral or cutaneous symptoms $12-72$ hours following traumatic skeletal injuries.

- Two widely accepted pathophysiologies of FES are mechanical obstruction and biochemical reaction.

- Findings on chest radiography are indistinguishable from acute respiratory distress syndrome due to other causes. Appropriate history and absence of cardiogenic pulmonary oedema will aid in the diagnosis.

- CT scan would show multiple areas of consolidation, ground-glass opacities and small nodules. 
consist of patchy or diffuse opacities in both lungs. ${ }^{23}$ Interstitial and nodular opacities may also be observed. ${ }^{2}$ History of long bone fractures along with absence of cardiogenic pulmonary oedema will aid in the diagnosis. ${ }^{3}$

CT scan shows multiple areas of consolidation, groundglass opacities and small $(2-10 \mathrm{~mm})$ nodules. These are predominantly seen in the upper lobes, whereas gravitydependent opacities are predominantly seen in the lower lobes. ${ }^{2}$ The nodules may represent inflamed intrapulmonary lymph nodes. Intravascular filling defects are less often described.

Treatment is largely supportive. This involves fluid resuscitation, oxygenation or mechanical ventilation. Symptoms are often transient with good prognosis (mortality $<1.2 \%$ ). Complete recovery is expected with adequate supportive care. ${ }^{1}$
Contributors The authors SCLO and VB have contributed sufficiently to the project and have met all criteria to be included as authors. All authors have not published or submitted any related papers from the same study.

Competing interests None declared.

Patient consent Obtained.

Provenance and peer review Not commissioned; externally peer reviewed.

(C) BMJ Publishing Group Ltd (unless otherwise stated in the text of the article) 2017. All rights reserved. No commercial use is permitted unless otherwise expressly granted.

\section{REFERENCES}

1 Weinhouse GL. Fat embolism syndrome. http://www.uptodate.com/contents/fatembolism-syndrome (accessed 05 Oct 2017).

2 Arakawa H, Kurihara Y, Nakajima Y. Pulmonary fat embolism syndrome: CT findings in six patients. J Comput Assist Tomogr 2000;24:24-9.

3 Han D, Lee KS, Franquet T, et al. Thrombotic and nonthrombotic pulmonary arterial embolism: spectrum of imaging findings. Radiographics 2003;23:1521-39.

Copyright 2017 BMJ Publishing Group. All rights reserved. For permission to reuse any of this content visit

http://group.bmj.com/group/rights-licensing/permissions.

BMJ Case Report Fellows may re-use this article for personal use and teaching without any further permission.

Become a Fellow of BMJ Case Reports today and you can:

- Submit as many cases as you like

Enjoy fast sympathetic peer review and rapid publication of accepted articles

- Access all the published articles

Re-use any of the published material for personal use and teaching without further permission

For information on Institutional Fellowships contact consortiasales@bmjgroup.com

Visit casereports.bmj.com for more articles like this and to become a Fellow 